\title{
An Investigation Of The Effect Of Reporting Alternatives For Fixed Assets On Financial Statement Users In The United States And The European Union
}

Linda M. Nichols, (E-mail: Linda.Nichols@ttu.edu), Texas Tech University

Kurt H. Buerger, (E-mail: Kurt.Buerger@angelo.edu), Angelo State University

\begin{abstract}
The European Union's decision to require consolidated statements in accordance with IASB standards will serve to greatly enhance the acceptance of IASB standards on a worldwide basis. For international standards to be accepted worldwide, they need to reflect the best reporting methods. One area in which diverse treatment is found is in the valuation of fixed assets. This study examines the effect of differing methods of fixed asset valuation on lending decisions made by bankers in the U.S. and the European Union represented by the countries of Germany and Austria. Bankers from these countries were asked to make a lending decision for a hypothetical company, which used either historical cost or fair value in reporting fixed assets. The results reveal a significant interaction effect between the home country of the respondent and the valuation method used. Specifically, the European bankers granted larger loans to companies reporting fixed assets at fair value, while U.S. bankers granted larger loans to companies reporting fixed assets at historical cost.
\end{abstract}

\section{Introduction}

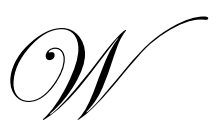

e are rapidly moving closer to having a truly global market for capital. As a result, the need and desire for accepted international accounting standards is becoming more pressing. Many countries already endorse the accounting standards issued by the International Accounting Standards Board (IASB) as their own, either without amendment or with minor additions or deletions. In 2001, the European Commission announced that it will require all listed companies in the European Union to publish consolidated financial statements in accordance with IASB standards beginning in 2005. Many companies within the European Union already adhere to IASB standards, even though it is not yet required. Other companies are currently working toward the transition to IASB standards.

The European Union's decision to require consolidated statements in accordance with IASB standards will serve to greatly enhance the acceptance of IASB standards on a worldwide basis. For international accounting standards to be accepted worldwide, they need to represent and require the best methods of financial reporting. One area where diverse treatment is found internationally is in how fixed assets are valued. This study examines the behavioral effects on decision makers from the United States (U.S.) and the European Union countries of Germany and Austria of differing methods of valuing fixed assets for financial reporting purposes.

Extensive research has been performed in international classifications of accounting systems. The pioneer work was performed by Mueller (1967), who used a deductive approach linking relevant environmental factors to national accounting practices in order to group countries. Nobes (1983), extended Mueller's classification, dividing countries into families, subclasses and classes. Under that classification, the U.S., United Kingdom (U.K.), Australia and Canada along with some other countries are considered to follow a microeconomic pattern in which 
accounting correlates closely with national economic policies. Germany, Austria, Japan, and Sweden, along with some other countries are classified as following a macroeconomic pattern which views accounting as a branch of business economics with a fundamental orientation toward individual economic entities. Germany and Austria were chosen as countries to be compared to the U.S. in this study due to the vast differences found in the accounting environment in those countries when compared to the U.S. In Germany and Austria, the influences of company law and taxation are very important. In contrast, the U.S. has adapted the U.K. accounting tradition which focuses more on large corporations and the interests of investors.

In this study, financial statement users are asked to make decisions based on differing valuation methods for fixed assets. The results of the study provide insight into how financial information is used by decision makers from countries with very different accounting systems. The remainder of this paper consists of discussion on background of valuations method for fixed assets, prior research, research design, response analysis, and conclusions.

\section{Valuation Methods}

U.S. GAAP requires that most assets and liabilities be accounted for and reported based on acquisition price. In its conceptual framework, the FASB identifies the historical cost principal and states that, "property, plant, and equipment and most inventories are reported at their historical cost, which is the amount of cash, or its equivalent, paid to acquire an asset, commonly adjusted after acquisition for amortization or other allocations" (FASB, 1984, par. 67a). Therefore, fixed assets are recorded at effective purchase price and depreciated over their useful lives. Fixed assets are not allowed to be revalued for appreciation in the U.S., but may be impaired if necessary under the rules of SFAS No. 144: Accounting for the Impairment or Disposal of Long-Lived Assets (FASB, 2001). While fixed assets might be written down if their market value decreases below book value, these same assets may never be written up if their market value increases above book value.

The European Union has been active in promoting harmonization in accounting and reporting standards within the member nations. To that end, the European Union has issued numerous directives which are generally followed by member states. Two of those directives, the Fourth and Seventh Directives, fundamentally address accounting harmonization. The Seventh Directive deals with consolidated accounts, while the Fourth Directive deals with a number of reporting issues including valuation methods. The Fourth Directive states that assets should be recorded at cost, but allows for alternative valuation approaches including current replacement cost, revaluations to fair market value, and price level adjustments. These alternative approaches are allowed to be used either in the main accounts or in supplementary statements (European Community, 1978).

The IASB has also addressed the issue of valuation of property, plant and equipment. According to international standards, property, plant and equipment should be initially measured at cost, but may be carried subsequently either at historical cost or at a revalued amount. The revalued amount reported is fair value at the date of revaluation less any subsequent accumulated depreciation or impairments (IASB, 1998). Therefore, companies following IASB standards may account for their fixed assets as U.S. companies do; recording them at historical cost, depreciating based on that historical cost, and not writing up assets when appreciation in value occurs. On the other hand, the companies are allowed to appreciate fixed assets on their balance sheet when their value increases above book value based on historical cost. The IASB standard is now becoming extremely relevant for European Union companies, as they approach the 2005 deadline for consolidation in accordance with IASB standards.

\section{Prior Research}

IASB standards allow for the use of fair value in the reporting of fixed assets. A stream of prior research has examined the relevance of fair value disclosures by examining the effect of fair value disclosures on security evaluation. The results of research on SFAS No. 33 in the U.S. (FASB, 1979), which required current and replacement costs disclosures is mixed. Beaver and Landsmen found that historical cost figures dominate current and replacement cost disclosures (1983). Several other studies also resulted in similar findings (Beaver et al., 1982; 
Beaver and Ryan, 1985; Bernard and Ruland, 1987). However, other studies have found that fair value disclosures have incremental explanatory power in security valuation (Bublitz et al., 1985; Murdoch, 1986; Haw and Lustgarten, 1988). These studies attribute the difference in their findings to errors in model specification including omitted variables in the aforementioned studies.

An investigation of how disclosed fair value estimates of banks' investment securities are reflected in share prices in comparison with historical costs was undertaken by Barth (1994). The findings of the study indicate that fair value estimates provide significant explanatory power beyond historical cost figures. The study also found that historical costs do not provide significant incremental explanatory power beyond fair value figures.

Other studies have attempted to assess both why companies choose to book revaluations and the effect of those revaluations on stock price. Cotter (1999) investigated whether managers of Australian firms use upward asset revaluations to reduce debt contracting costs. No significant association between debt contracting costs and revaluations was found. As additional analysis, Cotter interviewed chief financial officers. The conclusion drawn from these interviews was that close relationships between companies and their bankers caused firms to include footnote disclosures of fair values in preference to recording revaluations. Lin and Peasnell (2000) examined the relationship between fixed asset revaluations and equity depletion in the UK. Their results support a strong association between revaluations and the depletion of book equity due to the write-off of goodwill. A study by Jaggi and Tsui (2001) examined the motivation of managers in Hong Kong to revalue fixed assets. The results reveal that revaluations are positively associated with future performance, suggesting that managers use revaluations to signal the fair value of assets to users. The results indicated a positive relationship between revaluations and stock prices and returns, suggesting that the market's assessment aligns with the manager's revaluations. An earlier study of UK firms also found evidence that revaluations are positively related to future performance and annual returns (Aboody, et al., 1999).

While the results of prior research are somewhat mixed, several studies found that reported fair value amounts were relevant to participants in capital markets. Other studies have revealed that revaluations possibly serve as signals to the market. However, virtually none of these studies has taken a behavioral approach, but has instead examined market data. Behavioral evidence can be used to determine how decision makers are using financial information. This study utilizes a behavioral approach to determine the significance of fair value versus historical cost valuation methods to bankers from the U.S., and the two European Union countries of Germany and Austria.

\section{Research Design}

The research instrument consists of a complete set of annual financial statements for a fictitious candy company. Included are a balance sheet, income statement, statement of cash flows, and retained earnings statement. Notes to the financial statements are included, along with a description of the company with a "clean" audit opinion. The statements mailed to U.S. participants were for Laura's Chocolates, Inc., a fictitious company headquartered in the U.S. with foreign operations. The statements mailed to participants in Germany were for Alpha Schokoladen, a fictitious company headquartered in Germany with foreign operations, while the statements provided to Austrian participants were for Alpha Schokoladen, headquartered in Austria. The financial statements were converted from U.S. dollars into the local currency using the conversion rate in effect at the time of mailing. The statements were also translated from English into German before being sent to the German and Austrian bankers.

\section{The Variables}

The research design consists of a $3 \times 2$ factorial. The first factor is that of the country in which the participant is located. This factor has three levels, either the U.S., Germany, or Austria. The second factor is that of how fixed assets are valued for reporting purposes. This factor also has two levels, either historical cost or fair value.

The statements which utilize fair value for fixed assets report fixed assets at appraisal values, with depreciation also based on those revalued amounts. Footnote disclosure describes the company's policy of 
revaluing fixed assets. The statements which utilize historical cost accounting for fixed assets also disclose this policy in the footnotes. The statements utilizing fair value report net assets at an amount which is 29 percent higher than the amount reported on the historical cost statements. The historical cost statements report total income at an amount which is 6.9 percent higher than the income amount reported on the statements with revalued fixed assets. Income on the revalued statements is lower because the increased depreciation based on the fair value of fixed assets is greater than the positive revaluation amount for the year reported. In addition, a gain on the sale of plant assets is lower in the revalued statements because the difference between sales price and reported fair value is less than the difference between sales price and historical cost which is used to compute the gain in the historical cost statements. There are no other differences between the historical cost and fair value statements other than those caused by the revaluation of fixed assets. The first footnote of each set of statements sets out the policy for valuing fixed assets, either using historical cost or fair value.

Two dependent variables are used in this study. All subjects were asked to state the maximum amount they would be willing to lend the company on a five-year loan and the interest rate, stated as an amount above prime, that they would charge. They were told to assume a prime rate of 8 percent and that their bank had an unlimited amount of funds with which to make loans.

\section{The Banker Subjects}

The research instruments were mailed to 200 bank loan officers from each of the three countries. The names were obtained from the Thomson Global Banking Resource database. Each banker received one of the two sets of financial statements for the fictitious company headquartered in their home country. One set of statements used historical cost valuation for fixed assets, while the other set revalued fixed assets at their fair value. The subjects in each country were randomly assigned to receive statements using either historical cost or a revaluation of fixed assets. Banks with less than $\$ 75$ million (or the equivalent) in assets were not surveyed because it was believed that these banks would probably not be involved in making sizable commercial loans. One hundred fourteen completed instruments were obtained resulting in a 19 percent response rate. Table 1 presents descriptive information on the respondents. As reflected in the table, German and Austrian bankers were not as prone to participate in a study conducted by a U.S. university, but the number of responses received did allow for valid statistical testing.

Table 1: Description of Respondent Groups (assets in thousands of U.S. dollar equivalents)

\begin{tabular}{lccc}
\hline Group & $\begin{array}{c}\text { Number of } \\
\text { Respondents }\end{array}$ & $\begin{array}{c}\text { Mean of } \\
\text { Total Assets }\end{array}$ & $\begin{array}{c}\text { Mean Years Of } \\
\text { Lending Experience }\end{array}$ \\
\hline U.S. - HC & 22 & 452,812 & 13.79 \\
U.S. - FV & 21 & 474,510 & 17.95 \\
Germany - HC & 20 & 401,611 & 15.68 \\
Germany - FV & 18 & 420,714 & 14.72 \\
Austria - HC & 16 & 398,740 & 14.02 \\
Austria - FV & 17 & 379,530 & 16.70 \\
\hline
\end{tabular}

\section{Response Analysis}

The focal point of this study is to determine if the method of valuing fixed assets and/or the country the statement user is from has an affect on credit decisions made by bank loan officers. The principal model is a $3 \times 2$ MANOVA. A MANOVA is appropriate to use in this case because multiple dependent variables exist, loan amount and interest. MANOVA analysis is able to test for differences between means when there are multiple independent variables as well as more than one dependent variable.

The results of the MANOVA are shown in Table 2. Based on a significance level of .05 , only the interaction effect between the home country of the respondent and the method of valuation used is significant. This 
indicates that the decisions made are different depending on the home country of the respondent in conjunction with the valuation method used in the statements they received. When the MANOVA test statistic produces a rejection of the null hypothesis for a main effect or an interaction, separate univariate ANOVA designs "may suggest which of the elements of the vector variable are contributing most to the discrimination of the groups, or alternately, which variables are most affected by the treatments" (Cooley and Lohnes, 1971, p. 230). The ANOVA tests for differences between group means using one dependent variable at a time. Therefore, a two-factor $(3 \times 2)$ analysis of variance was performed for each response variable.

Table 2: Overall MANOVA Results

\begin{tabular}{lcl}
\hline Effect & F-Value & Prob. \\
\hline Valuation Method & .98 & .3786 \\
Country & 1.27 & .2828 \\
Valuation/Country Interaction & 8.57 & $.0001 *$ \\
\hline *Significant at the .05 level. & & \\
\hline
\end{tabular}

The results of the univariate test for the dependent variable of loan amount are presented in Table 3 . The ANOVA results indicate that the main effects are not significant. However, the interaction effect between the home country of the respondent and the valuation method used for fixed assets is significant at the .05 level. This indicates that the loan amount granted was affected by the home country of the respondent in conjunction with the valuation method used in the statements they received.

Table 3: Univariate ANOVA Results for the Response Variable of Loan

\begin{tabular}{lcl}
\hline Variable & F-Value & Prob. \\
Valuation Method & .28 & .5988 \\
Country & .33 & .7214 \\
Valuation/Country Interaction & 17.85 & $.0001 *$ \\
\hline * Significant at the .05 level. & &
\end{tabular}

A Duncan's Multiple Range test was performed in order to determine the groups between which there are significant differences. The results reveal that significantly larger loan amounts were granted by U.S. bankers receiving historical cost statements and by German and Austrian bankers receiving statements with fixed assets reported at fair value. The mean loan amount granted by the participants in each group is presented in Table 4 .

Table 4:Mean Loan Amounts Granted by Respondent Groups (in thousands of U.S. dollar equivalents)

\begin{tabular}{llc}
\hline Country & Valuation Method & Loan Amount \\
\hline United States & Historical Cost & $\$ 22,306$ \\
United States & Fair Value & 10,625 \\
Germany & Historical Cost & 13,500 \\
Germany & Fair Value & 22,463 \\
Austria & Historical Cost & 12,185 \\
Austria & Fair Value & 21,422 \\
\hline
\end{tabular}

The results of the univariate test for the dependent variable of interest rate premium are presented in Table 5. No significant effect was found. Interest rates given by the respondents were not affected either by the home 
country of the respondent, the valuation method used in the statements received, or by these two factors in combination.

Table 5: Univariate ANOVA Results for the Response Variable of Interest

\begin{tabular}{lcl}
\hline Variable & F-Value & Prob. \\
\hline Valuation Method & .33 & .5653 \\
Country & 2.28 & .1076 \\
Valuation/Country Interaction & .58 & .5627 \\
\hline
\end{tabular}

The mean interest rate premium charged by each response group is presented in Table 6. The figures reflect the findings of no significant differences in interest rates assigned by the respondents.

Table 6: Mean Interest Rate Premium Charged by Response Group

\begin{tabular}{llc}
\hline Country & Valuation Method & Interest Premium \\
\hline United States & Historical Cost & .3804 \\
United States & Fair Value & .3182 \\
Germany & Historical Cost & .3433 \\
Germany & Fair Value & .3625 \\
Austria & Historical Cost & .3250 \\
Austria & Fair Value & .3611 \\
\hline
\end{tabular}

\section{Conclusions}

The European Union will require that statements be consolidated according to IASB standards beginning in 2005. According to IASB standards, companies are allowed to report their property, plant and equipment at fair value. In the U.S., property, plant and equipment must be reported at historical cost, net of accumulated depreciation. This study sought to determine how the use of historical cost or fair value in the reporting of property, plant and equipment would effect credit decisions made by bank loan officers from three countries; the U.S., Germany, and Austria. The results reveal that the German and Austrian bankers granted significantly higher loans to companies reporting property, plant and equipment at fair value, while the U.S. bankers granted significantly higher loans to companies using historical cost.

The most probable reason for this difference lies in the high level of importance placed on reported income in the U.S. Financial statement users in the U.S. focus on the short-term bottom line, as is evidenced by market reactions to missed earnings projections. Net income was 6.9 percent higher on the historical cost statements.

In comparison, accounting in many European countries has followed a much more conservative tradition regarding the reporting of earnings. For example, in many European countries including Germany and Austria, any deduction claimed for tax purposes must also be charged in the annual accounts for financial reporting purposes. As a result to this conservative approach to income reporting, financial statement users do not focus heavily on bottomline income, but are more concerned with examining reported assets and liabilities. Assets were 29 percent higher on the statements with fixed asset revaluations.

There may be other reasons for the differences found in this study. In Austria and Germany, net income is highly related to taxable income. Therefore, companies which revalue assets will normally pay higher taxes. It might be assumed that only highly profitable firms would be willing to revalue when higher current tax payments result. If that assumption is accurate, then the revaluations may serve as a signal to statement users as to the profitability of these companies. This positive signal might prompt bankers to look more favorably on companies with revaluations of fixed assets. 
Alternately, bankers in the U.S. may have penalized firms with revaluations of property, plant and equipment to fair value simply because the bankers are not accustomed to seeing these fair value figures reported. Because the bankers were uncertain of the reliability of the fair value amounts, they may have applied a risk adjustment to the amount they were willing to lend these companies. If fair value reporting of fixed assets were to be allowed in the U.S. at some point in the future, financial statement users might eventually become more comfortable with using and relying on these fair value figures. As a result, financial statement users in the U.S. would not feel a need for a large risk adjustment, and the loan amounts granted companies with revalued fixed assets might increase.

Finally, U.S. bankers may have penalized firms with revaluations if the bankers assumed that the revaluations were booked in order to avoid bond covenant violations. Bond covenants are much more common in the U.S. than in the European Union. However, the subjects were not given information regarding bond covenants, so they would have had to assume this scenario as a possibility.

Accounting harmonization will be difficult to achieve due to variations in financial reporting found on a worldwide basis and because of differences in how information is being utilized by decision makers in different countries. Valuation methods used for the reporting of fixed assets is one such area where differences are found. This study provides evidence that the decisions of financial statement users are influenced by the valuation method used for fixed assets, either historical cost or fair value. It is difficult to say which of these reporting methods is superior. Historical cost figures are more reliable, but fair value amounts are more relevant. This study reveals that cultural and societal differences may influence users' preferences for historical cost or fair value information. European bankers look favorably upon fair value information, rewarding companies with fair value of property, plant and equipment greater than historical cost, with their willingness to make larger loans to those companies.

The European Union's mandate to consolidate according to IASB standards by 2005 is a positive move toward international accounting harmonization. This study reveals that even as acceptance of IASB standards spreads, financial statement users worldwide will still desire differing reporting methods, as are used in their decision models. Hopefully, the financial statement information needs of decision makers will also begin to converge as we move toward worldwide accounting harmonization. Unfortunately, the process of information needs convergence will most certainly lag behind accounting harmonization as users adjust to different ways in which information is reported. One way to help meet user needs on a global basis in the meantime, would be to prepare financial statements using either historical cost or fair value figures for fixed assets, but to disclose the alternative asset amounts and income effect. European companies could lead the way in this regard by disclosing both historical cost and such fair value information. Increased disclosures may be necessary, at least temporarily, to establish efficient global capital markets due to the fact that in some areas, such as in the reporting of fixed assets, one valuation method cannot now be seen as better due to differing user needs and wants currently found on a worldwide basis.

\section{References}

1. Aboody, D., M.E. Barth, and R. Kasznik. "Revaluations of Fixed Assets and Future Firm Performance: Evidence from the UK," Journal of Accounting and Economics, Jan. 1999, pp. 149-178.

2. Barth, M.E. 1994. "Fair Value Accounting: Evidence from Investment Securities and the Market Valuation of Banks," The Accounting Review, January, pp. 1-25.

3. Beaver, W.H. and W.R. Landsman. 1983. Incremental Information Content of Statement 33 Disclosures, FASB, (Norwalk, CT).

4. Beaver, W.H., P.A. Griffin, and W.R. Landsman. 1982. "The Incremental Information Content of Replacement Cost Earnings," Journal of Accounting and Economics, July, pp. 15-39.

5. Beaver, W.H. and S.G. Ryan. 1985. "How Well do Statement No. 33 Earnings Explain Stock Returns?," Financial Analysts Journal, Sept./Oct., pp. 66-71.

6. Bernard, V. and R. Ruland. 1987. "The Incremental Information Content of Historical Cost and Current Cost Numbers: Time Series Analysis," The Accounting Review, Oct., pp 701-722. 
7. Bublitz, B., T.J. Frecka, and J.C. McKeown. 1985. "Market Association Tests and FASB Statement No. 33 Disclosures: A Reexamination," Journal of Accounting Research, Supplement, pp. 1-23.

8. Cooley, W. \& P. Lohnes. 1971. Multivariate Data Analysis, (New York: John Wiley).

9. Cotter, J. 1999. “Asset Revaluations and Debt Contracting,” Abacus, Oct. 1999, pp. 268-285.

10. European Community. 1978. Fourth Council Directive for Coordination of National Legislation Regarding the Annual Accounts for Limited Liability Companies, (Brussels, EC).

11. Financial Accounting Standards Board. 1984. Statement of Financial Accounting Concepts No. 5: Recognition and Measurement in Financial Statements of Business Enterprises, (Norwalk, CT).

12. Financial Accounting Standards Board. 2001. SFAS No. 144: Accounting for the Impairment or Disposal of Long-Lived Assets, (Norwalk, CT).

13. Financial Accounting Standards Board. 1979. SFAS No. 33: Financial Accounting and Changing Prices, (Norwalk, CT).

14. Haw, I.M. and S. Lustgarten. 1988. "Evidence on Income Measurement Properties of ASR No. 190 and SFAS No. 33 Data,” Journal of Accounting Research, Autumn, pp. 331-352.

15. International Accounting Standards Board. 1998. IAS No. 16 Revised: Property, Plant and Equipment, (London, UK).

16. Jaggi, B. and J. Tsui. 2001. "Management Motivation and Market Assessment: Revaluations of Fixed Assets," Journal of International Financial Management and Accounting, Summer 2002, pp. 160-187.

17. Lin, Y.C. and K.V. Peasnell. 2000. "Fixed Asset Revaluation and Equity Depletion in the UK," Journal of Business Finance and Accounting, April/May 2000, pp. 359-394.

18. Magliolo, J. 1986. "Capital Market Analysis of Reserve Recognition Accounting," Journal of Accounting Research, Supplement, pp. 69-108.

19. Murdoch, B. 1986. "The Information Content of FAS 33 Returns on Equity," The Accounting Review, April, pp. 273-287.

Notes 